\title{
GREEK "HOMOSEXUALITY": WHITHER THE DEBATE?
}

\author{
Michael Lambert \& Holger Szesnat, University of Natal, Pietermaritzburg
}

\section{INTRODUCTION}

In this paper, we have attempted an overview of recent contributions to the debate surrounding "homosexuality" in ancient Greece during the classical period. We have both taught courses on sexuality in antiquity at an undergraduate and postgraduate level and have not yet come across a study which situates the debate taking place in classical studies in its broader intellectual framework, in such a way that it is accessible to anyone desiring an introduction to the field and suggestions for further research. We hope that this paper will address this need. We have confined ourselves to male "homosexuality" in ancient Greece as most of the literature is concerned with this phenomenon; however those interested in an introduction to female "homosexuality" in antiquity are referred to Dover (1989:171-184), Hallett (1979), Henderson (1988:1261-1263) and Lardinois (1989).

\section{THE THEORETICAL BACKGROUND}

In trying to understand the debate among classicists, it is useful to review some basic theoretical issues in the debate about "homosexuality". In order to review these theoretical issues, we will use the basic framework of the "essentialist" and "constructionist" controversy, the best example of which is precisely our subject, i.e. homosexuality. However, the debate is relevant for the whole complex issue of "sexuality in history" (cf. Padgug 1989:58-60).

\subsection{Essentialist vs. constructionist perspectives}

Before attempting to define the terms "essentialist / essentialism" and "constructionist / constructionism" (sometimes also called "social constructionism"), it needs to be stressed that these terms are somewhat problematic. On the face of it, they appear to refer to definite "camps" or "schools of thought" to which individual scholars or works can be attributed. However, theoretical positions on human sexuality are not usually clear-cut and straightforward. Therefore, "essentialism" and "constructionism" should be thought of as extremes on a continuum, although this continuum is not linear but multi-dimensional for example, one might have some strong essentialist and some strong constructionist beliefs at the same time. Thus. Epstein suggests that one should think of both essentialists and constructionists not as

a specific school, but rather as a broader tendency of thinking that has found representations in a number of disciplines (1987:14).

It is therefore preferable to speak of essentialist or constructionist "perspectives".

The terminology is problematic on another level as well: it was coined by one of the two sides, i.e. constructionists. Some of those scholars who are highly critical of 
"constructionism" (including those who have been labelled "essentialist") object that constructionists have created an hypothetical essentialist as a "bogey-man": this is necessary for the sake of symmetry in the controversy, but not fair to the actual positions held by such scholars (claims Dynes 1990a:216-7). In the same vein, it is also argued that constructionists are really debating with an illusionary partner (cf. Boswell 1989:34-35). Indeed, constructionists are often hard pressed to classify (contemporary) scholars with the label "essentialism", particularly in the historical field: usually, the only historical work cited is Boswell's Christianity, Social Tolerance, and Homosexuality (1980). What is important here is that those criticized by constructionists feel that the label does not depict their positions accurately; whether the essentialist label is actually fair to Boswell is a different matter.

To some extent, the division between essentialists and constructionists reflects the old "nature - nurture" debate: i.e. the question as to the extent of the influence of the environment on the individual, as opposed to hereditary influences (Epstein 1987:13; Halperin 1990a:42). Others liken the debate to the controversy of "nominalists" and "realists", originating in the middle ages (Boswell 1989:18-19; cf. Hacking 1986, Epstein 1987:13). Nevertheless, one should take care not to reduce the essentialist / constructionist controversy entirely to either (earlier) debate, as this would oversimplify the complexity of the issues involved.

\subsubsection{Essentialist perspectives}

Few (if any) scholars today who participate in the theoretical controversy concerning "essentialism / constructionism" would call themselves "essentialists". The ideal "strict essentialist" (as portrayed by constructionists) often reflects unconsidered popular sentiment rather than substantial scholarly works of the last fifteen years or so. However, we should note Vance's comment that to work with an essentialist perspective is still generally considered to be "normal" - therefore supposedly not requiring any methodological explanation. Indeed, she says:

For all of us, essentialism was our first way of thinking about sexuality and still remains the hegemonic one in the culture. $(1989: 14)$

There certainly is a considerable body of historical scholarship which comes very close to this "unreflected, popular understanding" (cf. Rowse 1977; Africa 1982), a position which can be called "naive essentialism" (Donaldson \& Dynes 1990:1333). It is this "naive essentialism", as opposed to more complex positions such as Boswell's (1989, 1990), which we wish to concentrate on in this section.

Essentialists tend to argue that sexuality is a fixed, given entity in any and every human being; they think that "there are objective, intrinsic, culture-independent facts" about a person's sexual object choice (Stein 1990b:5). Thus Epstein states:

Essentialists treat sexuality as a biological force and consider sexual identities to be cognitive realizations of genuine, underlying differences (...) there is considered to be some kind of "essence" within homosexuals that makes them homosexual - some gay "core" of their being, or their psyche, or their genetic make-up (1987:11).

Essentialists do not necessarily presume a biological (in the sense of hormonal, genetic, etc.) essence; the essentialist version of psychoanalytical thought would presume sexual "drives" which are inherent in the body or psyche, and which can only be controlled and 
channeled. However, all essentialists would argue that homosexuals (like heterosexuals) have some kind of innate "essence of being", which of course may be shaped differently by their environment, resulting in the varieties of sexual behaviour in different cultures. Essentialists believe that the categories "homosexual" or "heterosexual" "reflect an underlying reality of difference" (Epstein 1987:13). In this sense, an essentialist perspective implicitly regards sexuality as an ontological category, since sexuality becomes part of the "innermost core" or "being" of humans (cf. the discussion of "sexual identity" in Weeks 1987).

Important for historical (including classical) studies is that essentialists would generally assume that all cultures, throughout the ages, recognize that there are human beings who are physically attracted to members of the same sex, i.e. what we would call gay, lesbian, or homosexual. Categories such as "heterosexual" and "homosexual" (or gay and straight) are basically perceived as transhistorical. From an essentialist perspective, "homosexuality" can take various different "forms" in different times and cultures, but it can still be seen, described, analyzed (and "owned" as history by modern, western gays) as "homosexuality". "Naive essentialists" are thus able to regard certain historical figures as gays or lesbians, thus hoping to create "affectional ancestors" or role models (Dynes 1990a:215). On a much more sophisticated level, it is held to be possible to write a "history of gay people" spanning from republican Rome to the middle ages, as Boswell has done (1980). Scholars working from an essentialist perspective therefore tend to stress continuity between cultures and ages. As Bullough says: "homosexuality has always been with us; it has been a constant in history" (quoted in Halperin 1990a:159 n.21).

\subsubsection{Constructionist perspectives}

In general, constructionists tend to argue that sexuality is a social and cultural construct.1 This means, to put it simply, that a person's sexuality is determined by her / his society and culture. Constructionists argue that "sexuality" as such is not an independent category, objectively definable in every cultural and historical context: each culture determines what is "sexual" and what is not - indeed, cultures determine whether anything like a concept of "sexuality" exists at all. Concerning the terms "heterosexual" and "homosexual", constructionists tend to argue that

the experiences named by those terms are artifacts of specific, unique, and non-repeatable cultural and social processes (...) "constructionists" assume that sexual desires are learned and that sexual identities come to be fashioned through an individual's interaction with others (Halperin 1990a:41-2).

1 The "intellectual background" of constructionist perspectives is diverse (cf. Weeks 1981, 1982; Epstein 1987:14). Several distinct "sources" can be distinguished, especially: (a) sociological labelling theory (cf. McIntosh 1981; Plummer 1981b, 1981c) and "symbolic interactionist" approaches (cf. Gagnon \& Simon 1973; Plummer 1982); (b) the reinterpretation and further development of Freud's psychoanalytic work, especially through Lacan (1977), and, in different formi, by feminist scholars particularly during the 1970's (cf. Mitchell 1974; Turkle 1979); (c) the later work of Foucault, especially since the publication of his La volonté de savoir (1976). This list is not intended to be comprehensive: for example, one could mention Berger and Luckmann's significant work The social construction of reality (1966) as an important influence on the early development of constructionist thinking, even though it is hardly ever acknowledged by constructionists. In addition, socio-anthropological research during more recent years (eg. Herdt 1981, 1982, 1984, 1987; Ortner and Whitehead 1981) has also been influential among constructionists. 
Thus constructionists argue that whilst most known societies have examples of "sexual" behaviour between members of the same sex, the conception of "the homosexual" as a distinct type of a person (or species) is a relatively recent phenomenon. As Weeks notes:

The physical acts might be similar, but the social construction of meanings around them are profoundly different. (1981:81)

It is of interest to note in this regard that the very terms "homosexual" and "heterosexual" were only invented in the late 19th century, and indeed only became more current outside of the scientific debate during the twenties and thirties of the 20th century. 2 It is only from the late 19th century onwards, claims the constructionist historian Weeks, that we can observe

the categorization of homosexuality as a separate condition and the correlative emergence of a homosexual identity. (1981:81) ${ }^{3}$

We should take care to note here that most constructionists would not deny that there may always have been men who not only liked, but also preferred 4 to have sex with other men (or women with other women). What constructionists question is that such people always and everywhere (i.e. outside of the context of the late 19th and 20th century West) recognized themselves as "being gay / homosexual", i.e. that they regarded their preferential sexual object choice as something that determined their identity.

A constructionist critique of essentialist assumptions thus generally entails the claim that sexual categories are not fixed and largely immutable features of humankind. However, this does not imply that homosexuality (or heterosexuality) is merely a "figment of the imagination" (with the possible implication that it can be "cured"; see the discussion in Masters, Johnson \& Mass 1990). Thus Halperin emphasises:

Homosexuality and heterosexuality are not fictions inasmuch as there really are, nowadays, homosexual and heterosexual people, individuals whose own desires are structured according to the pattern named by those opposed and contrasting terms. No one ... would say that homosexuals or heterosexuals are simply imagining things, that they are deluded in supposing that they are attracted to one sex rather than another: they really do desire what they do, and that is a fact about them. (1990a:43; emphasis retained)

2 See Halperin's (1990a:15-18) gond summary of research on the appearance of the term "homosexuality", as well as its historical significance for a constructionist perspective.

3 It is important to note Vance's recent cautioning clarification: "social construction theory does not predict a particular answer: whether something we call "gay identity" existed in the 17th or 19th century, in London or in Polynesia, or whether 19th century female romantic friendship or crossing-women are properly called "lesbian", is a matter for empirical examination. Contemporary gay identity might exist in other times and cultures or it might not; its construction could be the same as we know it now, or radically different." (1989:15) Vance's clarification is important for constructionists since many tend to forget that whilst one may presume that there does not have to be a great deal of historical "continuity" between particular historical periods, research might actually show that there is more continuity than most constructionists today acknowledge. Conversely, for critics of constructionist perspectives to "prove continuity" (the most common means of criticizing constructionist theory) is not to disprove constructionist methodology (ibid. 17).

4 "Sexual preference" is not the same as "sexual orientation": the latter term is usually taken to imply some "innate" condition (essentialist), the former need not imply it (constructionist). 
Nonetheless, constructionists often tend to become vague, or simply refer to sketchily described "complex processes", when it comes to explaining exactly how (to take an example) modern, North American homosexuals "acquire" their sexuality and "sexual identity" - considering the fact that the dominant culture is (and has been for a long time) strongly heterosexist (cf. Halperin 1990a:42-45).

At any rate, in terms of constructionist historical methodology, this means that there is no such thing as "homosexuality" (or "heterosexuality") per se. Of course, the dominant expression and conceptualization of sexuality in Western cultures of the 20th century is indeed the one expressed by this pair of opposites. However, historians working with a constructionist perspective argue that it is misleading to impose this system of interpreting sexual experience (or rather, the experience of desire and pleasure) on earlier periods of Western history (or other cultures, for that matter), i.e. that it is deceptive to view the historical evidence through the lens of the modern "hetero"/"homo" distinction (cf. Halperin 1990a:45-6).

\subsection{The influence of Foucault}

For the purposes of this paper, some more general comments on the influence of Foucault's work on constructionist methodology (especially the problem of conceptualizing sexuality) should be of interest. This is particularly so as, in recent years, many of the scholars working on sexuality in antiquity have been influenced by him. Incidentally, Foucault, disliking labels, never called himself a constructionist (and this "label" would probably be incorrect anyhow). In fact, it appears that he tried to avoid being drawn into the essentialist / constructionist controversy. 5 The following, very brief elaboration largely focuses on the first volume of Foucault's History of Sexuality (1978); his studies in antiquity (cf. 1985a, 1985b, 1986) will be discussed in the second section of this paper. In this section, it should be noted, it is not our aim to criticize Foucault, but to describe his basic tenets briefly. 6

Foucault and those who make use of his pioneering studies claim that the very term "sexuality", and the conceptualization that accompanies it (i.e. that there is "a thing" like sexuality at all), is not necessarily present in cultures differing from the modern West. It is of interest in this context that Halperin, Winkler and Zeitlin recently published an important collection of essays entitled Before Sexuality (1990a). The title reflects the problem of conceptualizing "sexuality" in antiquity. Referring explicitly to the important influence of the work of Foucault, the editors explain the background to this phrase in the following way (1990b:5-6): the concept of "sexuality"

is a specifically modern production, a way of understanding experience (and therefore a way of experiencing) that is appropriate to a highly differentiated, industrialized, and modernized society. We now live, so the argument goes, with a model of personality centred on sex. Sexuality represents the most intimate feature of an individual, that dimension that ... reveals the truth about much of the rest [of the individual, H.S.]. A sexuality is a thing and I can have one. Indeed, each of us has his or her own sexuality, and we differ from

5 Note, for instance, his firm refusal to answer questions clearly directed at this problematic debate in an interview conducted in March 1982 (Foucaull 1982/83:11).

6 Critical literature on Foucault abounds. For a critical constructionist appreciation (incl. further literature) of "Foucault and sexuality", especially before the publication of vols. 2 and 3, see for instance Weeks (1981:98-103; 1982:302-7; 1989a:6-11). 
one another partly because sexualities differ. ... To be sure, a certain degree of identification of the self with the sexual self can be noticed in late antiquity and was strengthened by the Christian confessional; however, it did not become complete, explicit, and authoritative until the eighteenth- and the nineteenth century scientific construction of sexuality as a separate field of positivistic study.

In the first volume of his History of Sexuality (1978a; French original 1976), Foucault focussed on developments between the 17th and the 19th centuries. Foucault argued against what he called the "repressive hypothesis" (well summarized in Weeks 1982:294-5), the notion that Victorian sexual morality started to repress sexual lives, and that it was only during the later 20 th century in the West that people became sexually "liberated". Instead, Foucault argued, sexuality was (and is) just as incited, repressed, and encouraged (all at the same time) - for the purpose of control - as it was in the Victorian period; i.e. there really is no fundamental change between Victorian sexual discourse and the sexual discourse of the modern West. Victorian sexual discourse changed the way this discourse was held, but it did not alter the fundamental use and function of it. Of final importance in this connection is what Foucault also refers to as the link between "sexuality" and "truth" in the West (see Halperin et al. above): he sees

the West as bent on extracting the truth from sex ... A will to knowledge7 which is so imperious, and in which we are so enveloped, that we not only seek the truth of sex, but seek, through it, the truth about ourselves. We expect it to tell us about ourselves. (Foucault 1978b:6)

Foucault's work on sexuality is thus to be seen in the context of his interest in the relationship between individual, the self, and discourse (cf. Foucault 1988c; 1988d; 1993). We should also note here that Foucault's work on "sexuality" began as part of a much wider project: the study of power. For Foucault, Western medical discourse about sexuality, which suddenly intensified in the 19th century (and continues to be held in the present) formed "a formidable tool of control and power" (1988b:114). Discourse about sexuality (whether prohibiting or inciting, or -- more commonly -- both) is so important that few contemporary "systems of power" (e.g. states) can afford to neglect it (1988b:118); sexual discourse is productive and powerful. Both "power" and "sexuality", argues Foucault, must be seen as existing beyond the mere "prohibitive", negative definition (cf. 1988a:102-3): thus power is "not unitary, it does not reside in the state, it is not a thing to hold." (Weeks 1981:98) Foucault "widened" this traditional understanding of "power", encompassing the traditional definition only as one of its extreme manifestations:

the interdiction, the refusal, the prohibition, far from being the essential forms of power, are only its limits, power in its frustrated and extreme forms. The relations of power are, above all, productive. (Foucault 1988b:118).

In Foucault's work, "power" is first of all a relational term, as he already stated in the first volume (the "introduction") to his History of Sexuality:

It seems to me that power must be understood in the first instance as the multiplicity of force relations, immanent in the sphere in which they operate and which constitute their organisation; as the process which, through ceaseless struggles and confrontations transforms, strengthens, or reverses them (...) (Foucault 1978a:92).

7 Note that the title of the French original (1976) of Foucault's introduction to the History of Sexuality (1978a) is La volonte de savoir, which can be translated as "The will to knowledge". 
Because it is fundamentally "force relation", power can be said to be always coupled with resistance to it (1988b:123). Power inevitably and ceaselessly produces knowledge, creating a close relationship between power and knowledge -- so much so that Foucault often uses the complex "power / knowledge" in his work. Through "discourse", this power / knowledge is realized; in this sense, Foucault does not claim to be interested in "history of ideas", but history of discourse (Weeks 1981:99).

The "history of sexuality", like "power", is thus not to be studied solely as if it concerned only repression, interdict, disapproval, prohibition; with the underlying idea that once these negative forces are removed, "sex will be good again". Sexuality is much more complex than that, argues Foucault; thus its study needs to encompass the incitement to discourse as well:

We must write a history of sexuality which is not guided by the ideal of a repressive power, nor of a censorial power, but by the idea of an inciting power, of a knowing power. We must strive to locate the regime of coercion, of pleasure, and of discourse which is not inhibitive but constitutive of the complex domain of sexuality. (Foucault 1978b:8)

\section{THE CLASSICAL DEBATE}

It is in the second volume of The History of Sexuality (1985a; French original 1984) that Foucault begins his investigation into the process by which Western man (his words) began constituting himself as a desiring subject. From the philosophical and medical texts which he uses as sources for this (or rather which embody the ancient discourse on the aphrodisia), he deduces that the moral problematization of sex in Greco-Roman antiquity, as contrasted with the Christian period, is more concerned with askesis (training) of the self than with the codification of licit and illicit behaviours (1985a:30). What was of prime concern to the ancients in the practice of this askesis was the chresis aphrodision (the use of sexual pleasures) (ibid. 53) which had to be tailored, inter alia, to one's status in the community (ibid. 60) and regulated by the classical virtues of enkrateia (self-control) and sophrosyne (moderation; ibid. 63-65), as well as by a dietary regimen which trod the careful path of moderation between excess and defect (ibid. 101-114). The mastery of one's desires required a tough askesis of the soul (ibid. 72), an inherently masculine act, for it involved active struggle with the self rather than passive (and "feminine") surrender to pleasure (ibid. 82-84): this active struggle resulted in a freedom from the tyranny of the self (ibid. 78-80) and was therefore a virtue in the good ruler (ibid. 81). The ability to exercise power over oneself and power over others is thus in this branch of classical discourse inextricably linked to conceptions of gender.

Foucault's discussion of Greek "homosexuality" must be considered in this context. Like the constructionists mentioned earlier, he regards the notion of "homosexuality" as inadequate for describing "an experience, forms of valuation, and a system of categorization so different from ours" (ibid. 187). For the Greeks, male sexual desire for women or boys did not result in the kind of character typology with which we are familiar (homo-, hetero-, or bi-sexual): the Greeks did recognize preferences for one sex or the other, but this, argues Foucault, was a matter of taste, not involving the essence of the individual's being (ibid. 190). The chresis of pleasures in same-sex love demanded what Foucault calls a "special stylistics" (ibid. 192), precisely because this relationship involved two men from two distinct age-groups and with markedly disparate status (ibid. 194-195). As noted above, self-mastery, in the texts Foucault uses, was an active, masculine trait: for a man to surrender immoderately to pleasure would be unforgivably feminine. Thus 
complex social rituals and taboos surrounded these relationships, reflecting the society's concern about the conduct of both participants (ibid. 197). Moral discourses on this relationship were commonly concerned with the relationship itself (as the man and the boy, in contrast to the man and his wife, were independent agents with freedom of choice and movement) and with its precariousness (ibid. 201-202). Foucault integrates the relationship with the politics of honour and shame: in the transitional period between youth and manhood, the boy's future worth as a citizen was being tested (ibid. 206) and he had thus to make right chresis of the pleasures of same-sex eros, which were not wrong in themselves, but which could become so if the boy behaved passively and allowed himself to be dominated (ibid. 210-212), thereby assimilating himself to a slave or a woman (ibid. 216) or a male prostitute (ibid. 217-219), all of which belong to the realm of the dominated and passive. As sexual and social relations were isomorphically conceived, the role of the active penetrator was always essentially honourable (ibid. 215). Active and passive, masculine and feminine, penetrator and penetrated, dominant and dominated, citizen and non-citizen/minor - these are the polarities around which sexual relations were conceived, thus constituting immense difficulties for the boy who was expected to become a free subject, having mastered himself, but who was, at this stage of his life, the object of another man's pleasure (ibid. 221). Turning to philosophical texts like Plato's Symposium and Phaedrus, Foucault suggests that reflection on the "reciprocal ties between access to truth and sexual austerity" (ibid. 230) seems to have developed chiefly in relation to samesex love. For here Foucault perceives yet another kind of domination in the endless power game which characterises the domain of the aphrodisia: the domination of the "master of truth" who has so mastered himself that he can introduce the boy to the meaning of wisdom (ibid. 242-244).

The influence of Foucault is all-pervasive in the work of Winkler and Halperin8 who are amongst the most prominent contributors to the debate surrounding Greek "homosexuality" and the relationship between sexuality, gender and power in classical Athens. Both accept the fundamental Foucauldian premise that "sexuality" and, specifically, "homosexuality", as we now understand these constructs, are the creations of modern, Western, bourgeois discourse (Winkler 1990:4; Halperin 1990a:8). Halperin strengthens the evidence for this notion by examining the currency of the words "homosexual" and "homosexuality": both owe their creation to 19th century German scientific discourse (1990a:15, 155 n.2). Both Winkler and Halperin constantly reveal where their ideological allegiance lies by stressing that "sexuality" itself is a cultural construct (Halperin 1990a:25) and that a concept like "nature" is in itself a creation of ideological discourse (Winkler 1990:17). Furthermore Halperin argues that in antiquity sexual acts were categorised, not people on the basis of "sexual orientation" (1990a:26). Following on from Foucault, Halperin suggests that Athenian evidence tends to represent sex not as an act of mutual fulfilment, but as an act that one person does to another, for instance, an act performed by a male citizen on a statutory minor (a woman, boy or slave), which further supports Foucault's view that the sexual identities of classical Athenians are inextricably linked to their social and political

8 For favourable critiques of Winkler's work, see, for example, Nussbaum (1990:571-573); Clark (1991:424-426); Golden (1991:327-340); Steiner (1990-1991:507-508); Sutton (1991/92:189-191). For an unfavourable critique of Winkler's methodology, see Cohen (1992:146-147), who argues that Winkler fails to give a systematic account of the anthropological theories he purports to use. Golden (1991:327-340), Sutton (1991-1992:189191) and Cohen (1992: 150-153) review Halperin's work favourably, as does Dover (1991:161-163) and Makowski (1990-1991:407-408). Nussbaum (1990:571-573) is unusually critical of Halperin's methodology: it clearly smacks too much of Foucault for her taste. 
identities (Halperin 1990a:29-33; 47).9 "The social body precedes the sexual body" concludes Halperin; hence sexual behaviour is conceived of as an effect of socio-political relations (1990a:37). Gender issues are more fully explored in both Winkler and Halperin than in Foucault. Halperin demonstrates how sexual desire and behaviour in classical Athens are inseparably linked to gender constructs which portray "male desire as wideranging, acquisitive and object-directed and female as objectless, passive and determined by the female body's need for regular phallic irrigation" (ibid. 36). What Halperin perceives as Foucault's "first major conceptual breakthrough" is his clear ability to situate the Greek debate about sex into the context of "dietetics" - eating, drinking, sleeping and the proper use of these in order to ensure a balanced and healthy way of life: sex for the Greeks was no more or was as morally problematic as eating and drinking (ibid. 68).

Halperin is not uncritical of Foucault and critisizes him for faults other classical scholars have perceived: Foucault's "slapdash" use of source material often used out of context, his exclusive dependence on philosophical and medical texts, which obviously prejudices his account of the Greek mentalité, his concentration on discourse rather than action or behaviour (1990a:63).10 Yet Halperin believes that Foucault's account of the sexual morality of 5th and 4th century Greece is largely in agreement with the results of the best recent work on the topic (ibid.). By this he presumably means the work of Kenneth Dover, which Foucault used extensively: it was, after all, Dover's careful analysis of vasepaintings, 11 literary texts and oratory which resulted in the discussion of dominance and submission in Athenian sexual relations (1989:100-109).12 Dover perceived the very relationship between power, gender and sexuality which Foucault and his disciples were to develop in greater depth.

The debate surrounding Greek "homosexuality" has been given further impetus by the work of David Cohen $(1987,1991)$. Although Cohen resembles Foucault in arguing that there were no licit and illicit codes governing the morality of sexual behaviour in classical Athens, but rather regulation or "stylization" (to use a Foucauldian notion) of such behaviour, especially to keep its harmful effects out of the public sphere (1991:123, 221, 230-231), Cohen believes that Foucault's account of Greek "homosexuality" is too "univocal and homogenized" (1991:173; 1992:153). By this he seems to mean that Foucault underplays the extent of the ambivalence and conflicts which characterised Athenian attitudes to same-sex relations and sexual practices. Influenced by anthropological studies which have focussed on "conflict and contradiction as central features of cultural

For a clear discussion of the relationship between gender, social status and sexual behaviour in classical Athens, see Henderson (1988:1251-1258).

10 See, for example, Lefkowitz (1985:460-466), Nussbaum (1985:13-14) and Lloyd (1986:2428), who criticises Foucault for not studying ideas in the full complexity of their political setting. Walcot (1989:128) is particularly harsh on volume 3 of Foucault's History of Sexuality (1986): "This study is purely theoretical and suffers, grievously in my opinion, from being totally divorced from real life". For a favourable response from classical scholars, see Cameron (1986:266-271) and, of course, Halperin (1986b:274-286).

11 Cohen (1992:150-151) particularly stresses the influence of Dover on Foucault, Halperin and Winkler.

12 Golden mentions the newly-collected evidence from vase-paintings for the existence of the bearded eromenos, which might alter this analysis of dominance and submission. However, these may simply be unusual vases produced by a painter not concerned with the Athenian norm, as they were destined for a market with different norms (i.e. Etruria), as Golden points out (1991:333). 
systems" (1991:173), Cohen draws attention to the network of taboos and prohibitions (such as the law of hubris) which circumscribed the beh?viour of both the erastes and the eromenos, but especially the latter (1991:176-182). Cuhen argues that profound social anxiety about male-male erotic relationships was revealed in the atimia (the loss of political and civic rights) inflicted on those prosecuted for and convicted of male prostitution (ibid. 173). Significantly, Cohen draws on Aristophanes' speech in Plato's Symposium to challenge one of the fundamental premises of Foucault's (and Halperin and Winkler's argument): that the Athenians did not categorise people according to the dichotomy "homosexuality / heterosexuality" (ibid. 190-191). Using texts like Plato's Laws and Aristotle's Ethics, which explicitly condemn male-male sexual behaviour as "unnatural", Cohen concludes that there was no one "Athenian attitude" to homoeroticism, for a "culture is not a homogeneous unity" (ibid. 201).

Aristophanes' speech in Plato's Symposium deserves closer examination. Here Cohen believes that Aristophanes

presents heterosexuality and homosexuality as categories which are indeed both defined by nature: some individuals are naturally drawn to members of the opposite sex, others are attracted by their own sex (1991:190).

In his amusing account of the origins of various kinds of sexual attraction, Aristophanes does indeed classify human beings in four categories: male halves of the original androgyne whole are philogunaikes (lovers of women: 191d7), female halves philandroi (lovers of men: 191el); female halves of the original female whole are attracted to women and so hetairistriai ("lesbians" in modern idiom, comments Dover $1980 \mathrm{ad}$ loc.) arise from this genos (race: 191e2-5); male halves of the original male whole are attracted to men (191e6-192a2). Aristophanes adds that men in the latter category are not inclined to marriage and child-rearing by phusis (nature: 192b2), but are forced into it by nomos (custom: 192b2). Cohen firmly believes that this evidence in particular "reveals that Athenians were prepared to categorize human beings according to the dichotomy homosexuality / heterosexuality, both in the biological and social-sexual spheres" (1991:191). However, Cohen has been somewhat careless with the text here. Plato gives Aristophanes the words philogunaikes and philandroi, which loosely approximate our notion of "heterosexual", but when it comes to classifying what we would identify as "homosexual" women and men, Plato probably invents the word hetairistria (see LSJ s.v.) and then does not use a complementary classificatory term for a male "homosexual". Later in the same passage, Plato uses the terms paiderastes and philerastes for those men who prefer to spend their lives unmarried (192b3-5), but in the context of Athenian socialsexual mores, these terms are not equivalent to "homosexual" and can just as easily be used of men who are philogunaikes, but paiderastai before marriage. Furthermore, this is not the "Athenian" view, as Cohen claims, but the view of Plato, who is not demonstrably aware of the dichotomy "homosexuality / heterosexuality" as we know it.

Cohen in fact reproduces the views of Boswell, who argues that Aristophanes' speech strongly implies that there was an awareness of innate taxonomic categories like "homosexual" and "heterosexual" (1989:25-26; 1990:77) in antiquity even though the Greeks did not use the identity-focussed words (and hence categories) that we use. Halperin's critique of Boswell draws attention to the fact that Aristophanes has no place in his taxonomic scheme for adult males attracted to adult males; the notion of paederast and philerast (men loving boys and vice versa) is a qualification which Aristophanes introduces only in the case of those descended from the original male (Halperin 1990a:20-21). Hence we are not entitled to use the category "homosexual" of paederasts and philerasts, although Boswell sharply points out that the pair of males formed from the original male whole must have been of the same age (1990:84 n.25). From the tenor of the passage, however, 
Aristophanes clearly does not conceive of a category for attraction between males of the same age since this does not reflect the realities of same-sex love as Plato represented them.

As Cohen and, to a lesser extent, Winkler make use of contemporary Mediterranean anthropology to interpret the politics of sex and gender in ancient Greece,13 so other scholars have used comparative anthropological studies to interpret Greek "homosexuality". Bremmer $(1980 ; 1989 ; 1990)$ has been especially prolific in this regard and has argued, drawing imaginatively on evidence from quarters as diffuse as Dorian Crete and Sparta, Papua New Guinea, the Germans and Celts, 19th century Albania and the Attica prison revolt of 1972, that homosexual behaviour amongst the ancient Greeks was probably the relic of an Indo-European initiation rite during which older youths initiated younger, via "Rangdemonstration" (demonstration of social rank / status) like sodomy, into the mores of the community.14 Bremmer contrasts Greek pederasty and homosexualty:

Whereas modern homosexuals often occupy a marginal position in society and are regularly considered to be effeminate, in Greece it was pederasty that provided access to the world of the socially elite; it was only the pederastic relationship that made the boy into a real man. (1989:11)

Similarly, Patzer (1983) argues that Greek pederasty was such a specific kind of homosexual behaviour (he too makes use of the initiatory model) that applying the term "homosexuality" is misleading, for this pederasty was essentially lacking in erotic or "homosexual" desire. The initiation hypothesis and the use of comparative anthopological data have been acutely criticised by Dover, who believes that the evidence on which the initiation model is based is shaky, to say the least (1988:133). Halperin's criticism of Patzer is lively and perceptive (1990a:60):

In Patzer's case, the well-founded conviction that homosexuality-as-sexualinclination is a distinctively modern phenomenon leads him to impose on the Greeks, by way of hermeneutic rigor, a paederasty-without-homoeroticism for which there is no trace in either the historical or the ethnographic record.

Halperin discerns a sinister political agenda in Patzer's model of pederasty as a form of social ritual - the desire to free the Greeks from any charge of homoeroticism and so imply that for them heterosexuality was the norm (1990a:61).

\section{CONCLUSIONS}

As can be seen from the above outline of recent models which have been used for interpreting Greek "homosexuality", the debate is heavily influenced by the intellectual milieu in which it has taken place. The constructionist perspective, as evidenced in the work of Foucault, Halperin and Winkler, is clearly to be preferred to the position of Boswell, who is closer to the essentialist end of the essentialist $/$ constructionist

13 See MacDowell's pungent criticism of Cohen's methodology (1992:345-347).

14 Other scholars have also recently made use of this model. See, for example, Sergent (1987) and, to a lesser extent, Golden (1984). 
continuum.15 What is important is that this debate demonstrates the abiding relevance and importance of a study of classical antiquity (as Foucault's work in particular demonstrates): for in examining how the ancient Greeks conceived of sexuality, we can begin to appreciate the complexity of our own conception or constructs of sexuality and to challenge naive essentialist notions which are fundamental to the kinds of rigid antithetical thinking embedded in, for example, racism or homophobia. In this respect, trans-historical comparative studies could generate exciting possibilities for research. For example, Moodie's study (1989) of migrancy and male sexuality on the South African gold mines (during the period of the 1930's to 1950's) can be effectively compared with the constructionist studies of "homosexuality" in ancient Greece. Moodie's study of male-male mine marriages reveals some interesting similarities with the practice of classical Athens. Sexual relationships occured between older and younger men, who in turn became the lovers of younger men; inter-crural sex was common and anal sex not (ibid. 413); those involved in "homosexual" liaisons later married (ibid. 420-421); the relationship between older and younger men closely reflected the power structures in the mine hierarchy (ibid. 421-422). Differences between same-sex relationships on the mines and the practices of classical Athens are even more striking. The younger men in the relationships were often completely transformed into "wives" and were expected to behave and perform domestic duties like wives "back home" in the rural areas from which many of the miners had come (ibid. 416-417). Factors such as the unavailability of women on the mines (ibid. 414), the perceived dangers of liaisons with "town women" (ibid. 421) and fears of losing their "rural identity" helped shore up the system of same-sex mine marriages, which is in danger of collapse precisely because of the urbanization of many families and the consequent demise of the migrant labour system (ibid. 425). In his study, Moodie thus clearly illustrates that sexuality for the group of black miners studied was constructed in relation to social, political and economic factors. With the model of the heterosexual, rural marriage (in which the wife is the passive, dominated partner) as the norm, relationships with men were constructed, reflecting the power structures in the mines. There is evidence of considerable ambivalence about these relationships outside the mine environment (ibid. 415). In classical Athens, relationships with younger men were also constructed in direct relationship to political and social realities. The unavailability of citizen women before marriage may well have been a contributory factor to the existence of these relationships, as Dover has suggested (1989:88, 201-202); considerable ambiguity surrounded the position of the younger partner, as we have already discussed, but nowhere is there any evidence that the younger partners were "feminized" and were expected to perform "wifely duties." On the contrary, vase paintings depict homoerotic activity in a consciously "masculine" setting. However, the polarities of dominance and submission, of the active penetrator and the passive penetrated, are isomorphic with the structure of Athenian marriages. What this brief comparative study reveals is how sexuality in two very different societies, remote in time and place, is intimately connected with power structures and

15 Boswell refuses the idea of a debate because he believes that no current historian would consciously defend an essentialist position: he prefers to remain agnostic about the origins of human sexuality (1989:35-36). Although Boswell concedes that discourse about sexuality in antiquity was notably different from modern discourse and rarely concerned itself with what we term "orientation", "preference", or "identity" (1990:70), he still believes that there was a definite awareness of the basic dimorphism (homosexual / heterosexual) in antiquity, which received little attention because it had little social or ethical impact (1990:77, 81). Hence his history of gay people (1980). The word "consciously" is very significant. Historians may not consciously defend an essentialist position, but unconscious assumptions about homosexuality as a historical constant are surely features of a covert essentialism which underlies many historical accounts of sexuality. 
conceptions of gender. "Feminizing" men, in the context of a mine marriage, solves the position of the younger partner by incorporating him within the stereotypical gender boundaries with which the society of black miners is familiar. Ironically, the knowledge too that this relationship would be short-lived and would not survive outside the confines of the mine probably contributed to maintaining the situation. The younger Greek men were not "feminized", but many of the anxieties surrounding this position arose because the behaviour of the younger man could coincide with what the prevailing ideology demarcated as "feminine". In the all male society of the mine, the "feminization" of men could remain unchallenged because of the absence of women; the presence of women in classical Athens ensured that future citizen males could not trespass gender boundaries unchallenged. Moodie is right: sexuality has a social history (1989:425); it has a psychological one as well, which some constructionists tend to ignore, but the use of the category "homosexual" to encapsulate this history would be inappropriate both in the case of the classical Athenians and the black South African miners. Different societies at different moments in history have constructed sexuality differently; to understand and appreciate difference is one of the advantages of constructionist methodology. Essentialism tends to blur distinction in its claims about ahistorical sameness. Constructionist methodology also results in an understanding of the way in which historical discourse is coloured by ideology and manipulated by power interests: learning how to dissect the relationship between power, discourse and knowledge is one of Foucault's most important legacies. Similarly, dissecting the relationship between gender, sexuality and power in classical Athens has deepened our understanding of the Greeks and thus of ourselves.

\section{BIBLIOGRAPHY}

Africa, T. 1982. "Homosexuals in Greek history." Journal of Psychohistory 9:401-420.

Altman, D. et al. 1989. Homosexuality? Which homosexuality? International conference on Gay and Lesbian studies. Amsterdam: Uitgeverij An Dekker / Schorer. London: GMP.

Berger, P.L. \& Luckmann, T. 1966. The social construction of reality: a treatise in the sociology of knowledge. Harmondsworth: Penguin.

Boswell, J. 1980. Christianity, social tolerance, and homosexuality: gay people in Western Europe from the beginning of the Christian era to the fourteenth century. Chicago: University of Chicago Press.

Boswell, J. 1989. Revolutions, universals, and sexual categories, in: Duberman, M.B., Vicinius, M. \& Chauncey, G. (eds.) 1989. Hidden from history: reclaiming the Gay and Lesbian past. New York: New American Library (Penguin), 17-36.

Boswell, J. 1990. "Concepts, experience, and sexuality." Differences 2(1):67-87.

Bremmer, J. 1980. "An enigmatic indo-european rite: paederasty." Arethusa 13:279-98.

Bremmer, J. 1989. Greek pederasty and modern homosexuality, in: Bremmer, J. (ed.) 1989. From Sappho to de Sade: moments in the history of sexuality. London: Routledge, 1-14.

Bremmer, J. 1990. Adolescents, SYMPOSION, and pederasty, in: Murray, O. (ed.) 1990. Sympotica: a symposium on the Symposion. Oxford: Clarendon, 135-148. 
Cameron, A. 1986. "Redrawing the map: early Christian territory after Foucault." Journal of Roman Studies 76:266-276.

Clark, G. 1991. "The constraints of desire." Classical Review 41:424-426.

Cohen, D.J. 1987. "Law, society and homosexuality in classical Athens." Past and Present 117:3-21.

Cohen, D.J. 1991. Law, sexuality, and society: the enforcement of morals in classical Athens. Cambridge: Cambridge University Press.

Cohen, D.J. 1992. "Sex, gender, and sexuality in ancient Greece." Classical Philology 87:145-60.

Donaldson, S. \& Dynes, W.R. 1990. Typology of homosexuality, in: Dynes, W.R. (ed.) 1990. Encyclopedia of homosexuality 2. New York: Garland, 1332-1337.

Dover, K.J. (ed.) 1980. Plato: Symposium. Cambridge: Cambridge University Press.

Dover, K.J. 1988. Greek homosexuality and initiation, in: Dover, K.J. 1988. The Greeks and their legacy: collected papers 2: Prose literature, history, society, transmission, influence. London: Blackwell, 115-134.

Dover, K.J. 1989. Greek homosexuality. 2nd ed. (1978). London: Duckworth.

Dover, K.J. 1991. "Greek sexual choices." Classical Review 41:161-162.

Dynes, W.R. 1990a. Wrestling with the social boa constructor, in: Stein, E. (ed.) 1990. Forms of desire: sexual orientation and the social constructionist controversy. New York and London: Routledge, 209-238.

Dynes, W.R. 1990b. Social construction approach, in: Dynes, W.R. (ed.) 1990. Encyclopedia of homosexuality 2. New York: Garland, 1209-1210.

Dynes, W.R. (ed.) 1990c. Encyclopedia of homosexuality. 2 vols. New York: Garland.

Dynes, W.R. \& Donaldson, S. (eds.) 1992a. Homosexuality and religion and philosophy. New York: Garland.

Dynes, W.R. \& Donaldson, S. (eds.) 1992b. Homosexuality in the ancient world. New York: Garland.

Epstein, S. 1987. "Gay politics, ethnic identity: the limits of social constructionism." Socialist Review 93:9-54.

Foucault, M. 1976. La volonté de savoir: histoire de la sexualite I. Paris: Gallimard.

Foucault, M. 1978a. The history of sexuality 1: An introduction. New York: Pantheon.

Foucault, M. 1978b. "The West and the truth of sex." Sub-Stance 20:5-8.

Foucault, M. 1980a. Power / knowledge: selected interviews and other writings 19721977. Colin Gordon (ed.). Brighton: Harvester.

Foucault, M. 1980b. "The history of sexuality: interview." Oxford Literary Review 4:3-14.

Foucault, M. 1982. "The subject and power." Critical Inquiry 8:777-795.

Foucault, M. 1982/83. "Sexual choice, sexual act: an interview with Michel Foucault (interviewer: James O'Higgins)." Salmagundi 58/59:10-24. 
Foucault, M. 1985a. The use of pleasure Vol. 2 of: The history of sexuality. New York: Pantheon.

Foucault, M. 1985b. The battle for chastity, in: Ariés, P. \& Béjin, A. (eds.) 1985. Western sexuality: practice and precept in past and present times. Oxford: Blackwell, 14-25.

Foucault, M. 1986. The care of the self, vol. 3 of: The history of sexuality. New York: Pantheon.

Foucault, M. 1988a. On power, in: Kritzman, L.D. (ed.) 1988. Michel Foucault: politics, philosophy, culture: interviews and other writings 1977-84. New York: Routledge, 96-109.

Foucault, M. 1988b. Power and sex, in: Kritzman, L.D. (ed.) 1988. Michel Foucault: politics, philosophy, culture: interviews and other writings 1977-84. New York: Routledge, 110-124.

Foucault, M. 1988c. The concern for truth, in: Kritzman, L.D. (ed.) 1988. Michel Foucault: politics, philosophy, culture: interviews and other writings 1977-84. New York: Routledge, 255-267.

Foucault, M. 1988d. Technologies of the self, in: Martin, L.H., Gutman, H. \& Hutton, P.H. (eds.) 1988. Technologies of the self: a seminar with Michel Foucault. Amherst: University of Massachusetts Press, 16-49.

Foucault, M. 1993. "About the beginning of the hermeneutics of the self." Political Theory 21:198-227.

Foucault, M. \& Sennett, R. 1981. "Sexuality and solitude." London Review of Books 3(9):3-7.

Gagnon, J.H. \& Simon, W. 1973. Sexual conduct: the social sources of human sexuality. Chicago: Aldine.

Golden, M. 1984. "Slavery and homosexuality at Athens." Phoenix 38:308-324.

Golden, M. 1991. "Thirteen years of homosexuality (and other recent work on sex, gender and the body in ancient Greece)." Classical Views / Echos du Monde Classique 35:327-40.

Guédon, J.C. 1977. "Michel Foucault: the knowledge of power and the power of knowledge." Bulletin of the History of Medicine 51:245-277.

Hacking, I. 1986. Making up people, in: Heller, T.C., Sosna, M. \& Willbery, D.E. (eds.) 1986. Reconstructing individualism: autonomy, individuality, and the self in Western thought. Stanford: Stanford University Press, 222-236.

Hallett, J.P. 1979. "Sappho and her social context: sense and sensuality." Signs 4:447-464.

Halperin, D.M. 1986a. "Plato and erotic reciprocity." Classical Antiquity 5:60-80.

Halperin, D.M. 1986b. "Sexual ethics and technologies of the self." American Journal of Philology 107:274-286.

Halperin, D.M. 1990a. One hundred years of homosexuality and other essays on Greek love. New York: Routledge. 
Halperin, D.M. 1990b. Sex before sexuality: pederasty, politics, and power in classical Athens, in: Duberman, M.B., Vicinius, M. \& Chauncey, G. (eds.) 1989. Hidden from history: reclaiming the Gay and Lesbian past. New York: New American Library (Penguin), 37-53.

Halperin, D.M. 1990c. "The democratic body: prostitution and citizenship in classical Athens." Differences 2(1):1-28.

Halperin, D.M., Winkler, J.J. \& Zeitlin, F.I. (eds.) 1990a. Before sexuality: the construction of erotic experience in the ancient Greek world. Princeton: Princeton University Press.

Halperin, D.M., Winkler, J.J. \& Zeitlin, F.I. 1990b. Introduction, in: Halperin, D.M., Winkler, J.J. \& Zeitlin, F.I. (eds.) 1990. Before sexuality: the construction of erotic experience in the ancient Greek world. Princeton: Princeton University Press, 3-20.

Henderson, J. 1988. Greek attitudes toward sex, in: Grant, M. \& Kritzinger, R. (eds.) 1988. Civilization of the ancient Mediterranean: Greece and Rome. Vol. 2. New York: Scribner, 1249-1263.

Herdt, G.H. 1981. Guardians of the flute: idioms of masculinity. New York: McGrawHill.

Herdt, G.H. (ed.) 1982. Rituals of manhood: male initiation in Papua New Guinea. Berkeley: University of California Press.

Herdt, G.H. (ed.) 1984. Ritualized homosexuality in Melanesia. Berkeley: University of California Press.

Herdt, G.H. 1987. The Sambia: ritual and gender in New Guinea. New York: Holt, Reinhart and Winston.

Lacan, J. 1977. The four fundamental concepts of psycho-analysis. London: Hogarth.

Lardinois, A. 1989. Lesbian Sappho and Sappho of Lesbos, in: Bremmer, J. (ed.) 1989. From Sappho to de Sade: moments in the history of sexuality. London: Routledge, 15-35.

Lefkowitz, M. 1985. "Sex and civilization." Partisan Review 52:460-466.

Lloyd, G.E.R. 1986. "The mind on sex." New York Review of Books March 13, 24-28.

Macdowell, D.M. 1992. "The enforcement of morals." Classical Review 42:345-347.

McIntosh, M. 1981. The homosexual role, in: Plummer, K. (ed.) 1981. The making of the modern homosexual. London: Hutchinson, 30-44.

McIntosh, M., Plummer, K. \& Weeks, J. 1981. Postcript: the "homosexual role" revisited, in: Plummer, K. (ed.) 1981. The making of the modern homosexual. London: Hutchinson, 44-49.

Makowski, J.F. 1990/91. "Review." Classical World 84:407-408.

Masters, W., Johnson, V. \& Mass., L.D. 1990. Perspective in perspective: an interview with William Masters and Virginia Johnson, in: Mass, L.D. 1990. Homosexuality and sexuality: dialogues of the sexual revolution 2. New York: Harrington, 1-6.

Mitchell, J. 1974. Fsychoanalysis and feminism. London: Allen Lane. 
Moodie, T.D. 1989: Migrancy and male sexuality on the South African gold mines, in: Duberman, M.B., Vicinius, M. \& Chauncey, G. (eds.) 1989. Hidden from history: reclaiming the Gay and lesbian past. New York: New American Library (Penguin), 411-425. [earlier version in: Journal of Southern African Studies 14 (1988) 228256.]

Nussbaum, M. 1985. "Affections of the Greeks." New York Times Book Review November $10,13-14$.

Nussbaum, M. 1990. "The bondage and freedom of Eros." Times Literary Supplement June 1-7, 571-573.

Ortner, S.B. \& Whitehead, H. (eds.) 1981. Sexual meanings: the cultural construction of gender and sexuality. Cambridge: Cambridge University Press.

Padgug, R.A. 1989. Sexual matters: rethinking sexuality in history, in: Duberman, M.B., Vicinius, M. \& Chauncey, G. (eds.) 1989. Hidden from history: reclaiming the Gay and Lesbian past. New York: New American Library (Penguin), 54-64.

Patzer, H. 1983. Die griechische Knabenliebe. 2nd. ed. (1982). Wiesbaden: Steiner.

Plummer, K. (ed.) 1981a. The making of the modern homosexual. London: Hutchinson.

Plummer, K. 1981b. Building a sociology of homosexuality, in: Plummer, K. (ed.) 1981. The making of the modern homosexual. London: Hutchinson, 17-29.

Plummer, K. 1981c. Homosexual categories: some research problems in the labelling of homosexuality, in: Plummer, K. (ed.) 1981. The making of the modern homosexual. London: Hutchinson, 53-75.

Plummer, K. 1982. Symbolic interactionism and sexual conduct: an emergent pattern, in: Brake, M. (ed.) 1982. Human sexual relations: a reader in human sexuality. Harmondsworth: Penguin, 223-241.

Plummer, K. (ed.) 1992. Modern homosexualities: fragments of lesbian and gay experience. London: Routledge.

Rousseau, G.S. 1987. "The pursuit of homosexuality in the eighteenth century: 'utterly confused category' and / or rich repository?" in: Maccubin, R P (ed.) 1987. 'Tis nature's fault: unauthorized sexuality during the enlightenment. Cambridge: Cambridge University Press. 132-168.

Rowse, A.L. 1977. Homosexuals in history: a study of ambivalence in sociery, literature and the arts. London: Weidenfeld and Nicholson.

Sergent, B. 1987. Homosexuality in Greek myth. London: Athlone.

Stein, E. (ed.) 1990a. Forms of desire: sexual orientation and the social constructionist controversy. New York and London: Routledge.

Stein, E. 1990b. Introduction, in: Stein, E. (ed.) 1990. Forms of desire: sexual orientation and the social constructionist controversy. New York and London: Routledge, 3-9.

Stein, E. 1990c. Conclusion: the essentials of constructionism and the construction of essentialism, in: Stein, E. (ed.) 1990. Forms of desire: sexual orientation and the social constructionist controversy. New York and London: Routledge, 325-353.

Steiner, A. 1990/91. "Review." Classical World 84:507-508. 
Sutton, R.F. 1991/92. "The Greeks and sexuality." Classical Journal 87:189-191.

Thorpe, J. 1992. "The social construction of homosexuality." Phoenix 46:54-61.

Turkle, S. 1979. Psychoanalytic politics: Freud's French revolution. London: Burnett.

Vance, C.S. 1989. Social construction theory: problems in the history of sexuality, in: Altman, D. et al. 1989. Homosexuality? Which homosexuality? International conference on Gay and Lesbian studies. Amsterdam: Uitgeverij An Dekker I Schorer. London: GMP, 13-34.

Walcot, P. 1989. "Review." Greece and Rome 36:128.

Weeks, J. 1981. Discourse, desire and sexual deviance: some problems in a history of homosexuality, in: Plummer, K. (ed.) 1981. The making of the modern homosexual. London: Hutchinson, 76-111.

Weeks, J. 1982. The development of sexual theory and sexual politics, in: Brake, M. (ed.) 1982. Human sexual relations: a reader in human sexuality. Harmondsworth: Penguin, 293-309.

Weeks, J. 1985. Sexuality and its discontents: meanings, myths, and modern sexualities. London: Routledge.

Weeks, J. 1987. Questions of identity, in: Caplan, P. (ed.) 1987. The cultural construction of sexuality. London: Tavistock, 31-51.

Weeks, J. 1989a. Sex, politics and society: the regulation of sexuality since 1800. 2nd ed. (1981). London: Longman.

Weeks, J. 1989b. Against nature, in: Altman, D. et al. 1989. Homosexuality? Which homosexuality? International conference on Gay and Lesbian studies. Amsterdam: Uitgeverij An Dekker / Schorer. London: GMP, 199-213.

Winkler, J.J. 1990. The constraints of desire: the anthropology of sex and gender in ancient Greece. New York: Routledge. 